Article

\title{
Removal of Lead(II) from Synthetic Wastewater by Lavandula Pubescens Decne Biosorbent: Insight into Composition-Adsorption Relationship
}

\author{
Ali Q. Alorabi ${ }^{1}$, Fahad A. Alharthi ${ }^{2, *}$, Mohamed Azizi ${ }^{3}$, Nabil Al-Zaqri ${ }^{2} \oplus$, Adel El-Marghany ${ }^{2}$ \\ and Khaled A. Abdelshafeek ${ }^{4}$ \\ 1 Chemistry Department, Faculty of Science, Albaha University, P.O. Box: 1988, Albaha 65779, Saudi Arabia; \\ aalorabi@bu.edu.sa \\ 2 Department of Chemistry, College of Science, King Saud University, Riyadh 11451, Saudi Arabia; \\ nalzaqri@ksu.edu.sa (N.A.-Z.); amarghany@ksu.edu.sa (A.E.-M.) \\ 3 Chemistry Department, Faculty of Science and Arts, Albaha University, Qilwah 65941, Saudi Arabia; \\ mazizi@bu.edu.sa \\ 4 Chemistry Department, Faculty of Science and Arts (Almukhwah), Albaha University, \\ Albaha 65779, Saudi Arabia; kelbarbary@bu.edu.sa \\ * Correspondence: fharthi@ksu.edu.sa
}

Received: 23 September 2020; Accepted: 20 October 2020; Published: 24 October 2020

\begin{abstract}
In this work, the widely-abundant, cheap, wild plant Lavandula pubescens Decne was evaluated as an adsorbent for removing $\mathrm{Pb}(\mathrm{II})$ ions from wastewater. The chemical composition of the plant was partially isolated and characterized by the corresponding techniques, including gas chromatography-mass spectrometry, gas liquid chromatography, and FTIR spectroscopy. The adsorption capacity of the dried plant material for $\mathrm{Pb}(\mathrm{II})$ ions increased with increasing contact time, initial ion concentration, and temperature, while it decreased with increasing adsorbent dosage. The optimum condition for $\mathrm{Pb}(\mathrm{II})$ adsorption was determined as $550 \mathrm{mg} / \mathrm{L}$ initial metal concentration, $\mathrm{pH} \leq 7$, and 90 min of contact. The best fit for $\mathrm{Pb}$ (II) adsorption isotherms was the linear form of the Freundlich model; however, the maximum capacity indicated by Langmuir was $91.32 \mathrm{mg} / \mathrm{g}$. The experimental data fit better the pseudo-second-order kinetic model $\left(R^{2}=0.969\right)$, suggesting chemisorption process. Thermodynamic data revealed an endothermic, nonspontaneous, and adsorption process favored at higher concentrations.
\end{abstract}

Keywords: Lavandula pubescens; low-cost biosorbent; adsorption; lead ion removal; water treatment; GC-MS analysis

\section{Introduction}

Heavy metal contamination of water is a growing problem, because of the industrial and technological development and the wide use of the associated materials. Toxic heavy metals released during manufacturing processes pose a serious threat to the environment, due to their non-degradable character and high possibility of bioaccumulation, particularly in plants [1]. The intake and accumulation of heavy metals also have serious health consequences for humans, such as cancer, organ failure, nervous system disorder, growth retardation, etc. [2-4]. The toxicity of lead has been known since antiquity, and remains a problem today [5]. Lead can be found in water, soil, air, in water transport systems due to the corrosion of lead pipes, from industrial discharges, and through the use of leaded gasoline. Therefore, policymakers and researchers are looking for sustainable ways to treat wastewater containing toxic metals released from industrial sources. 
Established technologies for removing toxic metals from wastewater include membrane filtration [6], chemical precipitation [7], and ion exchange [8], as well as reverse osmosis and adsorption on activated carbon [9]. However, many of these methods are expensive, have unpredictable performance, and/or generate toxic byproducts that are difficult to manage. Hence, their applications are limited [9]. The adsorption technique is a relatively successful one, since it features a simple design, easy operation, and high separation efficiencies $[10,11]$. Activated carbon is the most common sorbent for separating heavy metal from wastewater. However, it still suffers from a high cost, problems in regeneration and disposal, and dissolution under extremely acidic conditions. Therefore, there is a growing research effort to find cheaper and greener alternative adsorbents [12-14].

Many researchers have used natural biomaterials, such as agricultural or plant wastes for immobilizing environmental pollutants, because they are inexpensive, renewable, abundant, environmentally friendly, and biodegradable [15]. Example adsorbents for removing toxic metals include vegetable peels, banana peels, coffee grounds, cactus, rice straw, wheat straw, Diplotaxis harra (wall rocket), and Glebionis coronaria (crown daisy) [9,15-19]. The biosorption processes could occur through different mechanisms (e.g., chemisorption, complexation, adsorption-complexation on surfaces and pores, ion exchange, microprecipitation, and sorption by physical forces). They are also influenced by many parameters modulating the interaction between the adsorbate and absorbent, such as $\mathrm{pH}$, initial metal ion concentration, biomass dosage, temperature, contact time, and the presence of other metal ions in solution $[4,15]$.

Lavandula pubescens (L. pubescens) belongs to the genus of lavender (Lamiaceae family). It grows abundantly as a shrub in the wild across Saudi Arabia. L. pubescens has been predominantly used in aromatherapy as a relaxant and a carminative, antimicrobial, antitumor, and sedative agent, owing to its phytochemical components, such as essential oil, flavonoids, coumarins, polyphenolics, alkaloids, and terpenes $[20,21]$. To our best knowledge, however, only a few studies have employed this plant material for heavy metal removal [22].

Herein, the dried aerial part of L. pubescens was used for the first time as adsorbent without any physical or chemical pretreatment for removing $\mathrm{Pb}$ (II) ions from water. This method does not require any toxic and costly material or complicated procedure. To gain better insight into the plant constituents-adsorption activity relationship, before the adsorption experiments, the plant was first characterized by gas chromatography-mass spectrometry (GC/MS), gas liquid chromatography (GLC), and Fourier transform infrared (FTIR) spectroscopy. Therefore, the following influencing parameters for adsorption were considered: the contact time, initial concentration of $\mathrm{Pb}$ (II) ions, adsorbent dosage, $\mathrm{pH}$, and temperature. The sorption equilibrium isotherms and kinetic data were also studied using different models.

\section{Materials and Methods}

\subsection{Materials}

\subsubsection{Chemicals}

Lead nitrate $\left(\mathrm{Pb}\left(\mathrm{NO}_{3}\right)_{2}, 99 \%\right)$, sodium hydroxide pellets ( $\left.\mathrm{NaOH}, 98 \%\right)$, potassium hydroxide pellets ( $\mathrm{KOH}, 85 \%)$, and nitric acid $\left(\mathrm{HNO}_{3}, 65 \%\right)$ were purchased from Alfa Aesar, Karlsruhe, Germany. Ethanol (EtOH, 96\%), methanol (MeOH, 99.8\%), hydrochloric acid $(\mathrm{HCl}, 36 \%)$, and sodium sulfate anhydrous $\left(\mathrm{Na}_{2} \mathrm{SO}_{4}\right)$ were procured from Fisher Chemical, Loughborough, UK. All chemicals were used as received without further treatments, unless otherwise stated.

\subsubsection{Biomass}

The aerial parts (stems and leaves) of L. pubescens Decne (LPD) plant were collected from the Albaha region in western Saudi Arabia during April 2018. The biomass was washed thoroughly with distilled water to remove external dirt and, subsequently, air-dried at room temperature until constant 
weight was reached. The dried material was ground using an electric grinder to obtain fine powder. This as-prepared material was then stored in a plastic bottle for further use in the solvent-extraction and adsorption experiments.

\subsubsection{Adsorbate}

A stock solution of $\mathrm{Pb}$ (II) $(1000 \mathrm{mg} / \mathrm{L})$ was prepared in distilled water. The working solutions were obtained by dilution and, when needed, the $\mathrm{pH}$ of the desired working solutions was adjusted using $0.1 \mathrm{M}$ of either $\mathrm{NaOH}$ or $\mathrm{HNO}_{3}$. The $\mathrm{pH}$ value was monitored by a Benchtop Orion 3 Star $\mathrm{pH}$-meter (Thermo Scientific, Beverly, MA, USA), previously calibrated with standard buffers. A standard curve of the lead(II) ions was established in the range 2-10 ppm. The sample concentrations were analyzed using flam atomic absorption spectroscopy (FAAS) (PinAAcle 900T, PerkinElmer, Waltham, MA, USA) with a deuterium lamp (BGC-D2) and air-acetylene flame. Accordingly, concentrations were calculated via Beer-Lambert law, with reference to the standard curve.

\subsection{Extraction of L. Pubescens Constituents}

The plant powder $(200 \mathrm{~g})$ was defatted with petroleum ether at $40-60^{\circ} \mathrm{C}$ using a Soxhlet apparatus. To remove the pigments, the petroleum ether extract was passed through fuller's earth, filtered, dehydrated over anhydrous sodium sulfate, and dried at $30{ }^{\circ} \mathrm{C}$ under reduced pressure, using a rotary evaporator to give a pale yellow residue $(3.8 \mathrm{~g})$. Subsequently, the residue was dissolved in hot acetone $(300 \mathrm{~mL})$ and left to settle down overnight at room temperature. The obtained precipitate was filtered, washed with cold acetone, and recrystallized from chloroform/methanol to finally afford $0.75 \mathrm{~g}$ white crystals, the precipitate (acetone insoluble fraction, AIF) representing the mixture of fatty alcohols and hydrocarbons. The filtrate, acetone soluble fraction (ASF) was evaporated till dryness (2.5 g residue) and subjected to saponification with $\mathrm{KOH} / \mathrm{MeOH}$ to afford an unsaponifiable fraction (USF) and total fatty acids fraction (FAF). The FAF was methylated with $\mathrm{MeOH} / \mathrm{HCl}$ to afford fatty acid methyl esters (FAME).

Alcoholic extract was obtained using aqueous methanol $90 \%$. Hence, $20 \mathrm{~g}$ of the dried powdered plant was macerated, sequentially, three times, each with $100 \mathrm{~mL} \mathrm{MeOH}$. The combined methanolic extract was evaporated in vacuo till dryness before FTIR analysis. The constituents of the lipid fractions (AIF, USF, and FAME) were identified by gas chromatography coupled mass spectrometry (GC/MS) and/or gas liquid chromatography (GLC), using the conditions described below.

\subsection{Identification of the Isolated Chemical Constituents}

\subsubsection{GC/MS Analysis of AIF}

The GC/MS analysis was carried out using a TRACE GC Ultra gas chromatograph from Thermo Scientific (Thermo Fisher Scientific Inc., Waltham, MA, USA), coupled with a Thermo-MS detector (ISQ Single Quadrupole Mass Spectrometer). The GC/MS system was equipped with a TG-5MS column (30 $\mathrm{m} \times 0.25 \mathrm{~mm}$ i.d., $0.25 \mu \mathrm{m}$ film thickness). Helium carrier gas was employed at a flow rate of $1.0 \mathrm{~mL} / \mathrm{min}$ and a split ratio of $1: 10$. The temperature program was $60^{\circ} \mathrm{C}$ for $1 \mathrm{~min}$, rising at $3.0^{\circ} \mathrm{C} / \mathrm{min}$ to $240{ }^{\circ} \mathrm{C}$, and held for $1 \mathrm{~min}$. The injector and detector were held at $240^{\circ} \mathrm{C}$. The sample was diluted at 1:10 $(v / v)$ in hexane, and $0.2 \mu \mathrm{L}$ of the mixture was injected each time. Mass spectra were obtained by electron ionization (EI) at $70 \mathrm{eV}$ in the $\mathrm{m} / \mathrm{z}$ range of 40-450. Most of the compounds were identified based on the authentic chemicals, Wiley Spectral Library collection, and National Institute of Standards and Technology (NIST) library.

\subsubsection{GLC Analysis of AIF and FAME}

The GLC analyses were performed on a Varian model 3700 GC instrument (Varian Inc., Palo Alto, CA, USA) equipped with a capillary column (AG-Bp-70, poly silphenylenesiloxane, $60 \mathrm{~m}$ length, $320 \mu \mathrm{m}$ internal diameter, $0.25 \mu \mathrm{m}$ film thickness). For the AIF, the following temperature program 
was used: starting $70{ }^{\circ} \mathrm{C}$ and rising at $4{ }^{\circ} \mathrm{C} / \mathrm{min}$ to $270{ }^{\circ} \mathrm{C}$. The injector and detector were held at $280{ }^{\circ} \mathrm{C}$ and $290^{\circ} \mathrm{C}$, respectively. For FAME, the temperature program was $70^{\circ} \mathrm{C}$ and rising at $4{ }^{\circ} \mathrm{C} / \mathrm{min}$ to $190^{\circ} \mathrm{C}$; and the injector and detector were held at $240^{\circ} \mathrm{C}$ and $280^{\circ} \mathrm{C}$, respectively. The flow rates of $\mathrm{N}_{2}$ and $\mathrm{H}_{2}$ were $30 \mathrm{~mL} / \mathrm{min}$, and that of air was $300 \mathrm{~mL} / \mathrm{min}$.

\subsection{FTIR Analysis}

Fourier transform infrared (FTIR) analysis of the as-prepared plant powder adsorbent and ethanolic extract were performed to identify the essential functional groups predominantly responsible for the material adsorption activity. The measurement was carried out using a Nicolet iS50 FTIR spectrophotometer (Thermo Scientific) equipped with an attenuated total reflection (ART) accessory, over the range $4000-650 \mathrm{~cm}^{-1}$, with a resolution of $4 \mathrm{~cm}^{-1}$ and total cycles of 32 .

\subsection{Adsorption Studies}

\subsubsection{Batch Adsorption Experiments}

The adsorption equilibrium of lead ion with LPD adsorbent was carried out in 50-mL Eppendorf tubes; agitated at $150 \mathrm{rpm}$, and at the suitable conditions. Thus, the following parameters were optimized: initial lead(II) ion concentration (10-550 ppm), adsorbent dosages (0.1-2 g), pH value of the solution (3-7), and temperature $\left(30-50{ }^{\circ} \mathrm{C}\right)$. For the kinetic adsorption study, the tubes were shaken for $0,20,30,60,90,120$, and 180 min under the following conditions $(2 \times 7$ tubes): LPD dose $0.2 \mathrm{~g}$, $\mathrm{Pb}^{2+}$ adsorption solution $50 \mathrm{~mL}, \mathrm{~Pb}^{2+}$ concentration $55 \mathrm{ppm}, \mathrm{pH}$ 6, temperature $25^{\circ} \mathrm{C}$, and agitation $150 \mathrm{rpm}$. After each experiment, the adsorbent LPD was removed by filtration (Whatman filter paper, No. 1) and the residual ion concentration in the filtrate was measured using FAAS. All the experiments were performed in duplicate and averaged.

\subsubsection{Adsorption Modelling}

The percentage of metal ion removal $(R e, \%)$ and the equilibrium adsorption capacity $\left(q_{e}, \mathrm{mg} / \mathrm{g}\right)$ were computed using the following equations:

$$
\begin{aligned}
R_{e} \% & =\left(\frac{C_{0}-C_{e}}{C_{0}}\right) \times 100 \\
q_{e} & =\frac{\left(C_{0}-C_{e}\right) V}{m}
\end{aligned}
$$

where $C_{0}$ and $C_{e}(\mathrm{mg} / \mathrm{L})$ are respectively the initial and equilibrium metal concentrations, $V(\mathrm{~L})$ is the volume of the metal solution, and $m(\mathrm{~g})$ is the mass of adsorbent used.

Adsorption isotherm was evaluated using Langmuir and Freundlich adsorption models [23]. The Langmuir model generally assumes monolayer adsorption, whereas Freundlich suggests a heterogeneous surface with an exponential distribution of active sites and their energies. The linear forms of the two isotherms can be expressed by Equations (3) and (4) [23].

$$
\begin{gathered}
\frac{C_{e}}{q_{e}}=\frac{1}{K_{L} q_{m}}+\frac{C_{e}}{q_{m}} \\
\ln q_{e}=\ln K_{F}+\left(\ln C_{e}\right) / n
\end{gathered}
$$

where $C_{e}, q_{e}$, and $q_{m}(\mathrm{mg} / \mathrm{g})$ have the same meaning as above, $K_{L}(\mathrm{~L} / \mathrm{mg})$ is the Langmuir constant, describing the adsorption affinity for the adsorbent, $K_{F}(\mathrm{mg} / \mathrm{g})$ is the Freundlich coefficient, reflecting the adsorption capacity, and $1 / n$ is the adsorption intensity, with the $n$ value describing whether the adsorption is a physical $(n<1)$ or chemical $(n>1)$ process. If $n=1$, then the adsorption is linear. 
To evaluate the adsorption kinetic, the pseudo-first-order (PFO) and pseudo-second-order (PSO) models were used as described, respectively, by Lagergren-Svenska and Ho-McKay [23,24]. The linear form of Lagergren first-order rate equation is:

$$
\log \left(q_{e}-q_{t}\right)=\log \left(q_{e}\right)-\frac{k_{1} t}{2.303}
$$

where $q_{e}$ and $q_{t}(\mathrm{mg} / \mathrm{g})$ are, respectively, the adsorption capacity of metal ion at equilibrium and after time $t(\mathrm{~min})$, and $k_{1}(1 / \mathrm{min})$ is the PFO rate constant.

The linear form of the second-order rate equation is:

$$
\frac{t}{q_{t}}=\frac{1}{k_{2} q_{e}^{2}}+\frac{t}{q_{e}}
$$

where $k_{2}$ is the PSO equilibrium constant $(\mathrm{mg} /(\mathrm{g} \cdot \mathrm{min}))$.

Adsorption thermodynamic parameters, including Gibbs free energy $\left(\Delta G^{\circ}\right)$, enthalpy $\left(\Delta H^{\circ}\right)$, and entropy $\left(\Delta S^{\circ}\right)$ were calculated using the van't Hoff model, Equations (7)-(9).

$$
\begin{gathered}
\Delta G^{\circ}=-R T \ln K_{s} \\
\ln K_{s}=-\frac{\Delta H^{\circ}}{R T}+\frac{\Delta S^{\circ}}{R}
\end{gathered}
$$

where

$$
K_{s}=\frac{q_{e}}{C_{e}}
$$

where $K_{s}(\mathrm{~L} / \mathrm{g})$ is the apparent equilibrium constant, $\mathrm{R}(8.314 \mathrm{~J} /(\mathrm{mol} \cdot \mathrm{K}))$ is the universal gas constant, $T(K)$ is the adsorption temperature; all the other parameters reflect the same meaning as described in the isotherms above.

\section{Results and Discussion}

\subsection{Chemical Constituents in the Lipid Fraction}

The lipid constituents in the plant were extracted with petroleum ether and fractionated to acetone insoluble fraction (AIF), unsaponifiable constituents (USF), and fatty acids. The AIF was analyzed by GC/MS (Table 1) and found to contain at least 10 hydrocarbons, of which the main compounds were $n$-octacosane $\left(\mathrm{C}_{28} \mathrm{H}_{58}, 30.34 \%\right)$ and hexatriacontane $\left(\mathrm{C}_{36} \mathrm{H}_{74}, 27.50 \%\right)$. The USF was analyzed with GLC, and the data are summarized in Table 2. This fraction contained $n$-hydrocarbons, triterpenes, and sterols. The hydrocarbon fraction accounted for about $93.05 \%$ of the weight, and included 16 identified components, with docosane $\left(\mathrm{C}_{22} \mathrm{H}_{46}\right)$ being the major one $(23.54 \%)$. The triterpene fraction contained only one compound, which was identified as amyrine. The sterol fraction was composed of three compounds (cholesterol, stigmasterol, and sitosterol), with stigmasterol as a principal component (3.4\%). 
Table 1. GC/MS data of acetone insoluble fraction of L. pubescens Decne extract.

\begin{tabular}{cccccc}
\hline Peak No. & $\mathbf{R}_{\mathbf{t}}(\mathbf{m i n})$ & Rel. $\%$ & Formula & Mol. wt. & Compounds \\
\hline 1 & 42.41 & 2.37 & $\mathrm{C}_{22} \mathrm{H}_{46}$ & 310 & $n$-Docosane \\
2 & 48.76 & 3.06 & $\mathrm{C}_{23} \mathrm{H}_{48}$ & 324 & $n$-Tricosane \\
3 & 51.13 & 6.56 & $\mathrm{C}_{27} \mathrm{H}_{56}$ & 380 & $n$-Heptacosane \\
4 & 52.40 & 30.43 & $\mathrm{C}_{28} \mathrm{H}_{58}$ & 394 & $n$-Octacosane \\
5 & 54.14 & 2.15 & $\mathrm{C}_{29} \mathrm{H}_{60}$ & 408 & $n$-Nonacosane \\
6 & 54.42 & 7.62 & $\mathrm{C}_{29} \mathrm{H}_{60}$ & 408 & 2-Methyloctacosane \\
7 & 55.13 & 5.63 & $\mathrm{C}_{30} \mathrm{H}_{62}$ & 422 & $n$-Triacontane \\
8 & 56.56 & 9.72 & $\mathrm{C}_{35} \mathrm{H}_{72}$ & 492 & $n$-Pentatriacontane \\
9 & 57.41 & 27.86 & $\mathrm{C}_{36} \mathrm{H}_{74}$ & 506 & $n$-Hexatriacontane \\
10 & 62.7 & 4.60 & $\mathrm{C}_{44} \mathrm{H}_{90}$ & 618 & $n$-Tetratetracontane \\
\hline
\end{tabular}

$R_{t}$ is the retention time and Rel.\% is the relative percentage in the chromatogram.

Table 2. GLC data of USF of Lavandula pubescens Decne (LPD).

\begin{tabular}{ccccc}
\hline Peak No. & $\mathbf{R}_{\mathbf{t}}(\mathbf{m i n})$ & Rel. $\%$ & Chemical Formula & Compounds \\
\hline 1 & 7.74 & 3.85 & $\mathrm{C}_{13} \mathrm{H}_{28}$ & Tridecane \\
2 & 11.35 & 1.98 & $\mathrm{C}_{16} \mathrm{H}_{34}$ & Hexadecane \\
3 & 12.74 & 3.07 & $\mathrm{C}_{17} \mathrm{H}_{36}$ & Heptadecane \\
4 & 14.22 & 8.08 & $\mathrm{C}_{18} \mathrm{H}_{38}$ & Octadecane \\
5 & 15.65 & 10.01 & $\mathrm{C}_{19} \mathrm{H}_{40}$ & Nonadecane \\
6 & 16.55 & 8.25 & $\mathrm{C}_{20} \mathrm{H}_{42}$ & Eicosane \\
7 & 18.33 & 8.26 & $\mathrm{C}_{21} \mathrm{H}_{44}$ & Heneicosane \\
8 & 19.48 & 23.54 & $\mathrm{C}_{22} \mathrm{H}_{46}$ & Docosane \\
9 & 21.021 & 5.97 & $\mathrm{C}_{23} \mathrm{H}_{48}$ & Tricosane \\
10 & 22.319 & 2.55 & $\mathrm{C}_{24} \mathrm{H}_{50}$ & Tetracosane \\
11 & 22.964 & 4.04 & $\mathrm{C}_{25} \mathrm{H}_{52}$ & Pentacosane \\
12 & 24.680 & 2.24 & $\mathrm{C}_{26} \mathrm{H}_{54}$ & Hexacosane \\
13 & 25.258 & 5.92 & $\mathrm{C}_{27} \mathrm{H}_{56}$ & Heptacosane \\
14 & 26.433 & 2.71 & $\mathrm{C}_{28} \mathrm{H}_{58}$ & Octacosane \\
15 & 26.965 & 1,84 & $\mathrm{C}_{29} \mathrm{H}_{60}$ & Nonacosane \\
16 & 27.674 & 1.09 & $\mathrm{C}_{30} \mathrm{H}_{62}$ & Triacontane \\
17 & 30.369 & 0.96 & $\mathrm{C}_{27} \mathrm{H}_{46} \mathrm{O}$ & Cholesterol \\
18 & 31.132 & 3.40 & $\mathrm{C}_{29} \mathrm{H}_{48} \mathrm{O}$ & Stigmasterol \\
19 & 32.468 & 1.54 & $\mathrm{C}_{29} \mathrm{H}_{50} \mathrm{O}$ & $\beta$-Sitosterol \\
20 & 35.062 & 1.05 & $\mathrm{C}_{30} \mathrm{H}_{50} \mathrm{O}$ & $\alpha$-Amyrine \\
\hline
\end{tabular}

The fatty acids mixture (Table 3) was found to contain eight acids: four saturated ones $(59.48 \%)$ with palmitic acid $(23.69 \%)$ as a main one, and four unsaturated acids $(40.54 \%)$ with oleic acid as the main one (14.23\%). Our results differ from those reported by Gouda et al. and Akhlaghi et al. [25,26]. Those authors analyzed the unsaponifiable matter of L. pubescens growing in Egypt, and identified 5-hydroxy1,3,4-trimethoxy-7-methyl-6propar-naphthalene (36.64\%) as the major component followed by hentriacontane $(8.09 \%)$. Regarding fatty acids, oleic acid $(12.72 \%)$ was the major fatty acid methyl ester, in line with the results of Akhlaghi et al. [26], who identified the main fatty acid methyl esters in the leaf and stem of Lavandula officinalis collected from Iran as $\alpha$-linolenic acid (43.2 and 21.0\%, respectively), oleic acid (3.4 and 14.5\%), and palmitic acid (7.4 and $12.4 \%$ ). 
Table 3. Gas liquid chromatography (GLC) data of fatty acid methyl esters (FAME) fraction of L. pubescens Decne.

\begin{tabular}{ccccc}
\hline Peak No. & $\mathbf{R}_{\mathbf{t}}(\mathbf{m i n})$ & Rel. $\%$ & Notation & Compounds \\
\hline 1 & 21.15 & 23.69 & $\mathrm{C} 16(0)$ & Palmitic acid \\
2 & 25.06 & 14.51 & $\mathrm{C} 18(1)$ & Oleic acid \\
3 & 26.03 & 8.99 & $\mathrm{C} 18(2)$ & Linoleic acid \\
4 & 27.04 & 13.72 & $\mathrm{C} 18(3)$ & Linolenic acid \\
5 & 28.65 & 11.24 & $\mathrm{C} 20(0)$ & Arachidic acid \\
6 & 29.48 & 3.30 & $\mathrm{C} 20(4)$ & Arachidonic acid \\
7 & 30.75 & 3.24 & $\mathrm{C} 22(0)$ & Behenic acid \\
8 & 32.45 & 21.31 & $\mathrm{C} 24(0)$ & Lignoceric acid \\
\hline
\end{tabular}

The FTIR spectra of the adsorbent (LPD) and their alcoholic extract are shown in Figure 1. As can be seen, the majority of the functional groups can be identified, allowing the estimation of the adsorption active sites of the biosorbent under investigation. Both spectra exhibited prominent peaks at 3300, 2910, and $1645 \mathrm{~cm}^{-1}$, while peaks at 1400,1300,1100, and $1041 \mathrm{~cm}^{-1}$ were clearer in the alcoholic extract. However, the reduced intensity of some peaks in the spectra of the LPD, compared to the extract, may be due to the bulky materials, compared to the less complicated contents in the extract. The broad absorption band at $3300 \mathrm{~cm}^{-1}$ was assigned to stretching vibrations of hydroxyl functionality in the alcoholic and carboxylic $\mathrm{OH}$ groups, while the stretching vibration of $(\mathrm{NH}) \mathrm{C}=\mathrm{O}$ peptide carbonyl groups appeared at $1645 \mathrm{~cm}^{-1}$, with shoulders around $1750 \mathrm{~cm}^{-1}$ indicating additional different type of carbonyl groups. Peaks corresponding to the aromatic $\mathrm{C}=\mathrm{C}$ double bonds could be assigned at $1510 \mathrm{~cm}^{-1}$. The band at $1400 \mathrm{~cm}^{-1}$ was due to $\mathrm{C}-\mathrm{C}$ and $\mathrm{C}-\mathrm{N}$ stretching, and the peak at $2910 \mathrm{~cm}^{-1}$ was assigned to $\mathrm{C}-\mathrm{H}$ (e.g., methoxy compounds) stretching vibrations. The peak at $1041 \mathrm{~cm}^{-1}$ corresponds to $\mathrm{C}-\mathrm{O}$ stretching vibration of organic compounds, such as ethers, esters, and amides.

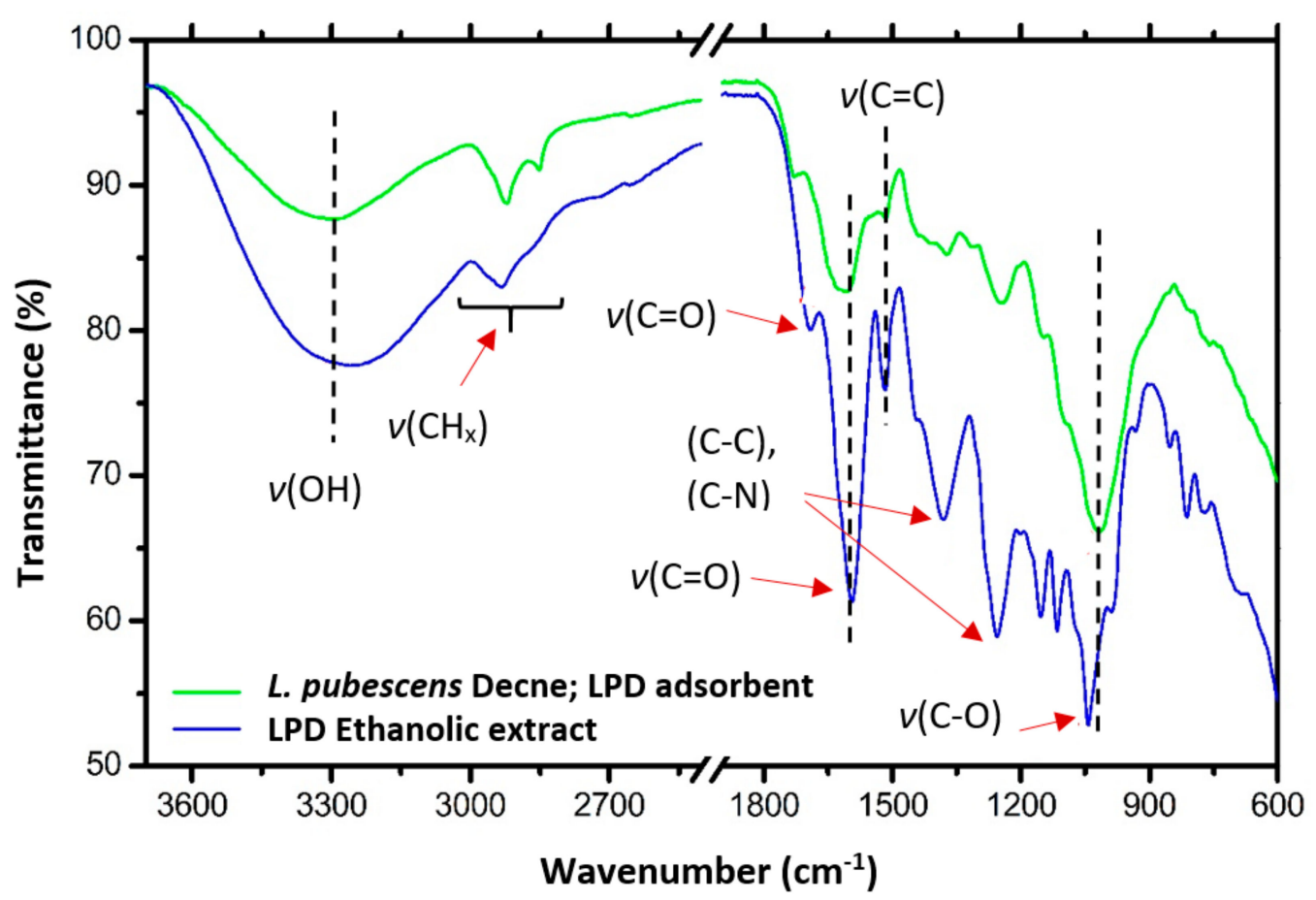

Figure 1. Fourier transform infrared spectra of the adsorbent LPD (green-colored spectra) and the ethanol extract (blue-colored spectra).

Accordingly, in addition to the hydrocarbons, the GC/MS and GLC analysis indicate the presence of adequate amounts of hydroxyl-, carboxyl-, and amide-containing organic compounds such as 
sterol, cholesterol, and long-chain saturated and unsaturated fatty acids. These molecules with polar functional groups $(\mathrm{OH}, \mathrm{COOR},(\mathrm{NH}) \mathrm{C}=\mathrm{O}$, and $\mathrm{COOH})$ may play a major role in the interaction with metal ions, providing the adsorbent with the negative charges, and thus increase their adsorption. The FTIR spectra of the dry powder and the extract (Figure 1) clearly showed that hydroxyl, carboxylic, and ester functional groups existed in the plant powder and extract.

\subsection{Adsorption Efficiency of LPD Biomass}

\subsubsection{Effect of Contact Time}

Figure 2 shows the adsorption profile of $\mathrm{Pb}^{2+}$ onto LPD adsorbent over the adsorption period of 0-180 min. It is obvious that, under the applied adsorption conditions, two phases of sorption behavior are present: a relatively fast, initial one from 0 to $90 \mathrm{~min}$, followed by a slow, final phase up to $180 \mathrm{~min}$, the pseudo-equilibrium, with experimental adsorption capacity $\left(q_{e}\right)$ of $4.12 \mathrm{mg} / \mathrm{g}$ and removal percentage $\left(R_{e}\right)$ of $32 \%$. The rapid adsorption in the first stage of adsorption can be attributed to the high availability of vacant sites on the adsorbent surface for the heavy metal ions occupation. By reaching the last stage of adsorption, the adsorbed ions cause increased repulsive forces, making the remaining sites difficult to be accessed, resulting in reduced adsorption rate [27]. Similar findings were reported, using banana peels and Ulva lactuca for the removal of $\mathrm{Pb}$ (II) and $\mathrm{Cd}(\mathrm{II})[28,29]$, and Schoenoplectus californicus plant for the removal of $\mathrm{Cr}$ (III) and $\mathrm{Pb}$ (II) [30].

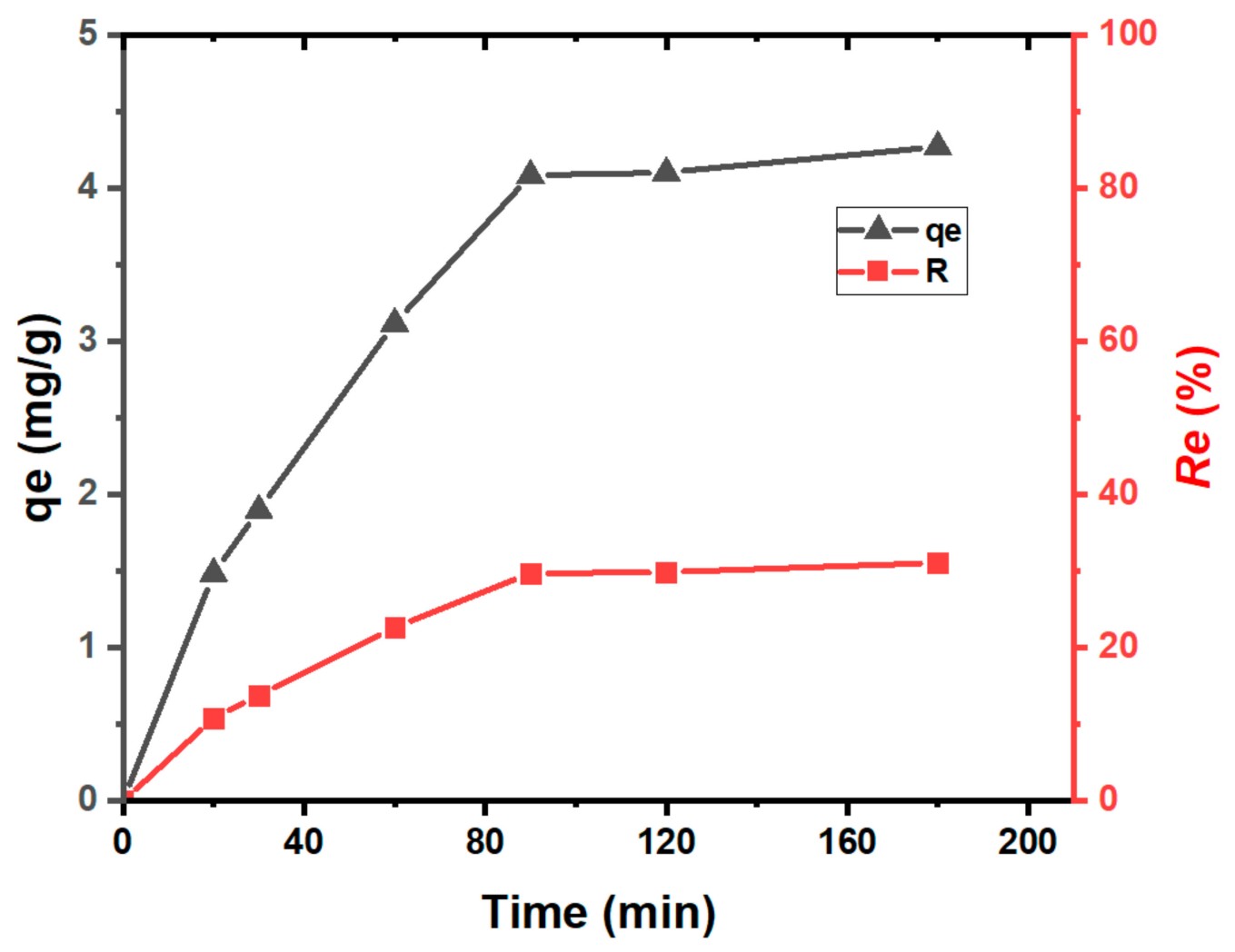

Figure 2. Effect of contact time on the adsorption capacity and removal percentage of lead(II) ions onto LPD. Conditions: $55 \mathrm{ppm} \mathrm{Pb}^{2+}$ concentration, $50 \mathrm{~mL} \mathrm{~Pb}^{2+}$ solution volume, $0.2 \mathrm{~g}$ LPD adsorbent dose, $\mathrm{pH} 6,25^{\circ} \mathrm{C}$ adsorption temperature, and $150 \mathrm{rpm}$ agitation speed.

\subsubsection{Adsorption Kinetics}

The measured adsorption kinetic data were fitted to the linear forms of Lagergren PFO and PSO equations (Equations (5) and (6)). The two models were applied to estimate the adsorption constants $\left(k_{1}\right.$ and $\left.k_{2}\right)$ as well as the correlation coefficients $\left(\mathrm{R}^{2}\right)$ values for $\mathrm{Pb}^{2+}$. The results are presented in Figure 3 
and Table 4. According to the data obtained, the values of $q_{e}(6.91 \mathrm{mg} / \mathrm{g})$ and $R^{2}(0.969)$ of the PSO model are more acceptable, describing kinetic behavior with $q_{e}$ value closer to the experimental one $\left(q_{e}\right.$. Exp.; $4.12 \mathrm{mg} / \mathrm{g}$ ) compared with that from PFO (15.10 and 0.946, respectively), indicating that the PSO model fits the experimental data better [31]. Therefore, the rate-limiting step of $\mathrm{Pb}^{2+}$ adsorption seems to be controlled by a chemical adsorption process via, for example, exchanging of electrons between the adsorbent and adsorbate [32], however, the physical adsorption process cannot be ignored, at least in the last stage of adsorption period. The initial adsorption rate $(h ; \mathrm{mg} /(\mathrm{g} \cdot \mathrm{min}))$ can be calculated from the data of the PSO model, as expressed in Equation (10). However, the calculation indicates low value of $h(0.095 \mathrm{mg} /(\mathrm{g} \cdot \mathrm{min})$ at the applied adsorption conditions (Table 4).

$$
h=k_{2} q_{e}^{2}
$$

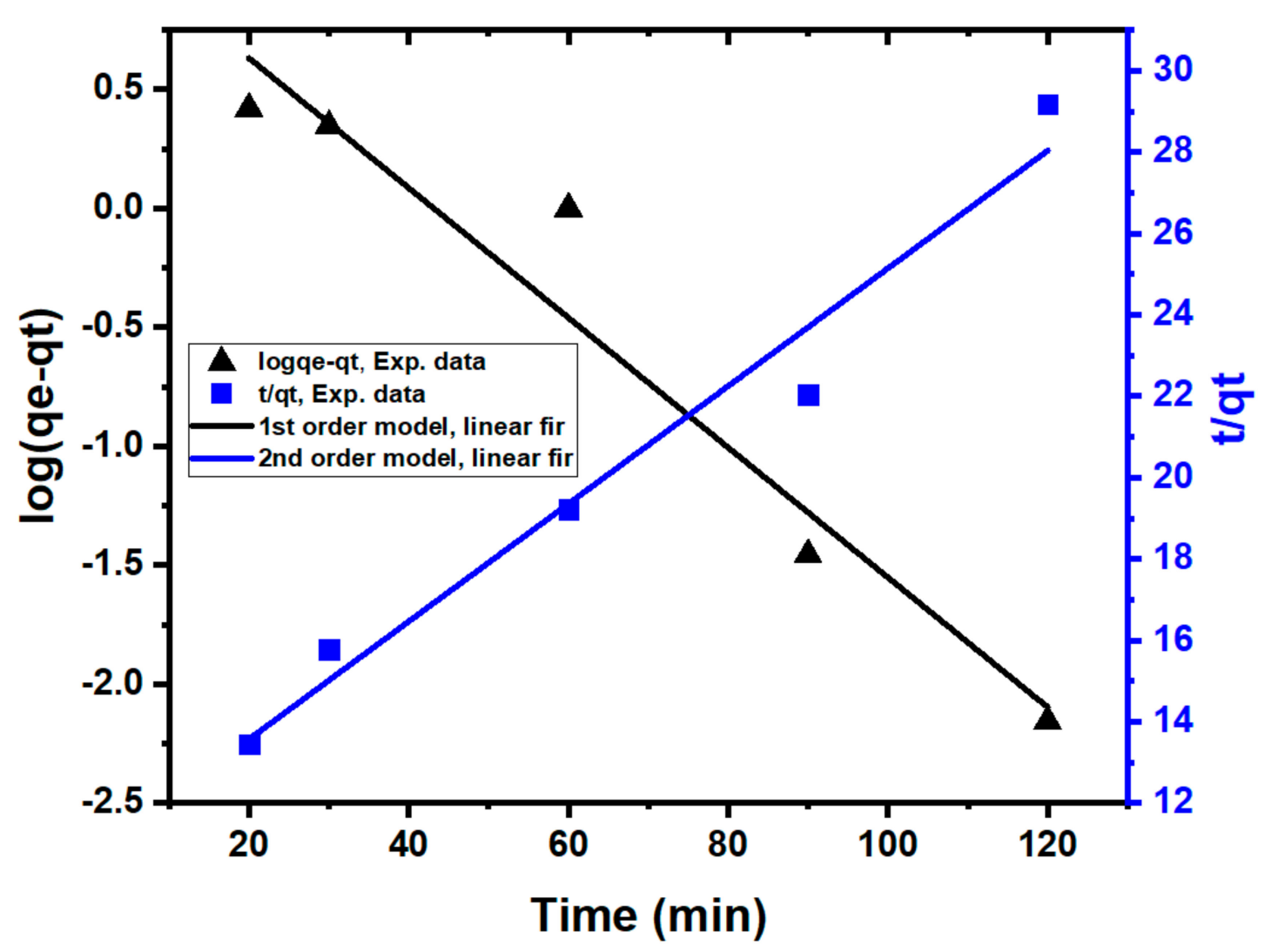

Figure 3. Pseudo-first and pseudo-second order kinetic models for adsorption of $\mathrm{Pb}^{2+}$ onto LPD. Conditions: $55 \mathrm{ppm} \mathrm{Pb}^{2+}$ initial concentration, $50 \mathrm{~mL} \mathrm{~Pb}^{2+}$ solution volume, $0.2 \mathrm{~g}$ LPD adsorbent dose, $\mathrm{pH} 6,25^{\circ} \mathrm{C}$ adsorption temperature, and $150 \mathrm{rpm}$ agitation speed.

Table 4. Kinetic parameters of pseudo-first and pseudo-second order equations for lead(II) adsorption onto LPD.

\begin{tabular}{cccccccc}
\hline \multirow{2}{*}{$q_{e}$ Exp. $(\mathrm{mg} / \mathrm{g})$} & \multicolumn{3}{c}{ Pseudo-First-Order } & \multicolumn{4}{c}{ Pseudo-Second-Order } \\
\cline { 2 - 9 } & $\boldsymbol{q}_{\boldsymbol{e}}(\mathrm{mg} / \mathrm{g})$ & $\boldsymbol{k}_{\mathbf{1}}(\mathbf{1} / \mathrm{min})$ & $\boldsymbol{R}^{\mathbf{2}}$ & $\boldsymbol{q}_{e}(\mathrm{mg} / \mathrm{g})$ & $\boldsymbol{k}_{\mathbf{2}}(\mathrm{g} /(\mathrm{mg} \cdot \mathbf{m i n}))$ & $\boldsymbol{R}^{\mathbf{2}}$ & $\boldsymbol{h}(\mathrm{mg} /(\mathrm{g} \cdot \mathrm{min}))$ \\
\hline 4.12 & 15.10 & 0.063 & 0.946 & 6.91 & 0.0020 & 0.969 & 0.095 \\
\hline
\end{tabular}

\subsubsection{Effect of Solution $\mathrm{pH}$}

The $\mathrm{pH}$ of solution is a crucial parameter that affects the adsorption process, by influencing both the solubility of the metal ions and the surface characteristics of adsorbent in the aqueous solution [33]. The effect of $\mathrm{pH}$ on the biosorption of $\mathrm{Pb}(\mathrm{II})$ ions by L. pubescens biomass was studied 
in the $\mathrm{pH}$ range from 3 to 7 . In Figure $4 \mathrm{a}$, the maximum adsorption capacity was at $\mathrm{pH}=5$ $\left(q_{e}=12.86 \mathrm{mg} / \mathrm{g}\right)$. However, a slight difference with $\mathrm{pH} 7(12.55 \mathrm{mg} / \mathrm{g})$ was observed. At $\mathrm{pH}$ lower than 5 (i.e., acidic medium), the additional $\mathrm{H}^{+}$compete with the metal cations for active sites on the biomass surface [33], and also repel the metal ions from the surface by electrostatic force. Hence, the adsorption capacity is reduced. In contrast, with $\mathrm{pH}$ increase, negatively charged functional groups on the LPD surface (such as carboxyl, phosphate, phosphodiester, sulphonate, and imidazole) attract the positively charged metal ions, and enhance their adsorption [30]. As the $\mathrm{pH}$ value increases above 7 , however, the $\mathrm{OH}$ ions increase in solution and react with the metal ions to form hydroxide precipitates and, therefore, adsorption experiments could not be performed well [34]. From these observations, it can be concluded that the adsorption efficiency of $\mathrm{Pb}^{2+}$ ions by L. pubescens biomaterial increases as the $\mathrm{pH}$ value approaches $\mathrm{pH} 5$. According to literature $[29,30]$, before precipitation occurrence of $\mathrm{Pb}(\mathrm{OH})_{2}$ at $\mathrm{pH}>7$, the slight decrease in biosorption of lead(II) at $\mathrm{pH}$ between 5 and 7 is due to the formation of soluble hydroxide complexes of the lead ions, which compete for the active sites and, as a consequence, decrease the adsorption efficiency. Such competition between biosorption, lead-hydroxyl complexation, and precipitation of the lead ions commonly occurs at pHs close to neutrality ( $\sim \mathrm{pH} 7)$ [30]. The chromatography and FTIR analysis indicate that the LPD biosorbent contains dominant organic-based polar or negatively-charged functional groups, such as hydroxyl, carboxyl, ester, amide, and amine; thus, ionic interaction, as one possible adsorption mechanism, with LPD is facilitated by complex formation between metal ions and functional groups on the adsorbent. Moreover, the chemisorption mechanism is supposed to be the dominant mechanism, at least in the first stage of adsorption.
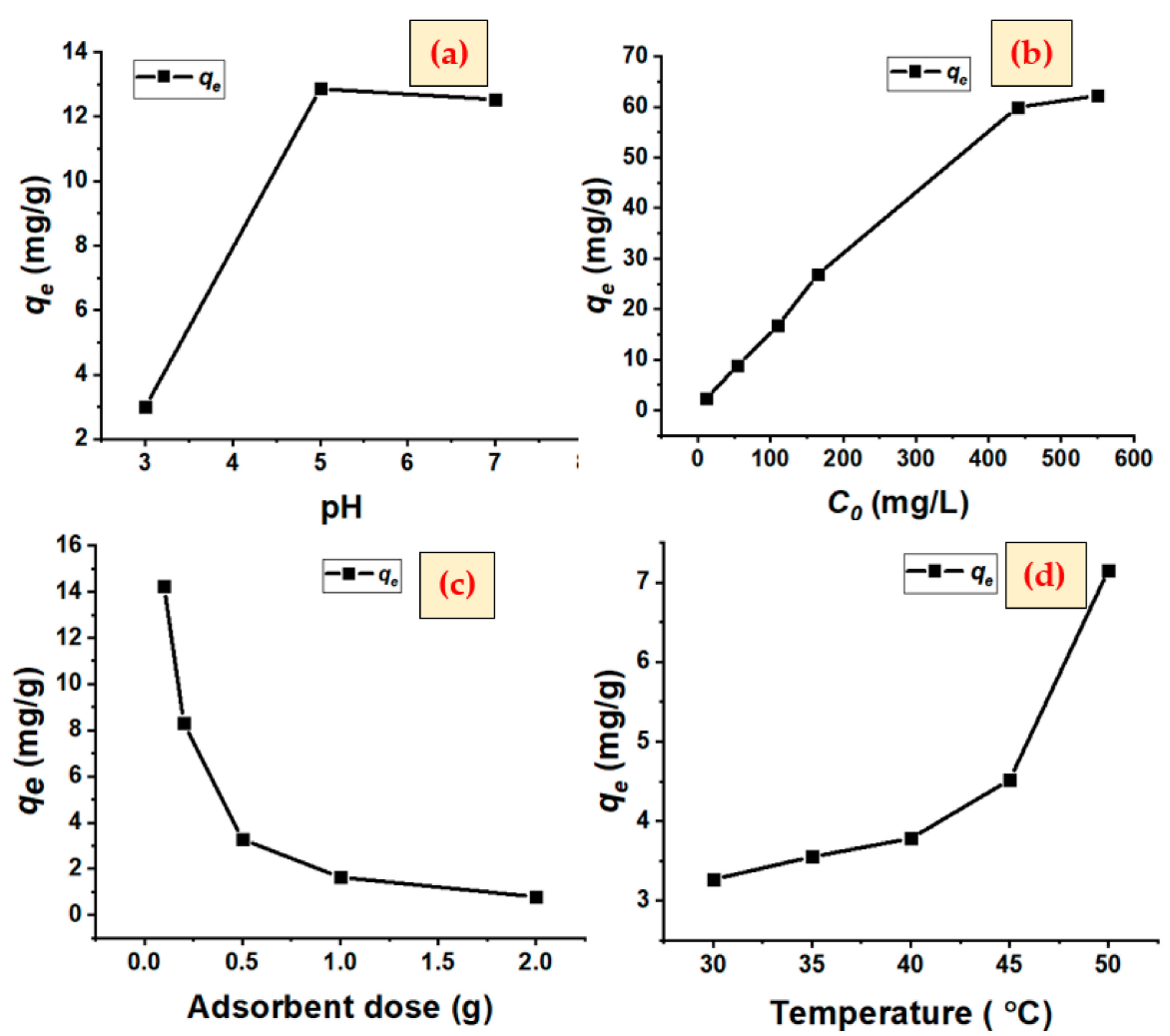

Figure 4. Effect of (a) $\mathrm{pH}$ value $\left(\mathrm{C}_{0}=55 \mathrm{ppm}, 0.2 \mathrm{~g} / 50 \mathrm{~mL}\right.$ adsorbent dose, temperature $=25{ }^{\circ} \mathrm{C}$, and $150 \mathrm{rpm}$ agitation speed), (b) initial lead(II) concentration $(0.2 \mathrm{~g} / 50 \mathrm{~mL}$ adsorbent dose, $\mathrm{pH} 6$, temperature $=25^{\circ} \mathrm{C}$, and $150 \mathrm{rpm}$ agitation speed $)$, (c) adsorbent dosage $\left(\mathrm{C}_{0}=55 \mathrm{ppm}, 50 \mathrm{~mL}\right.$ adsorbent volume, $\mathrm{pH}$ 6, temperature $=25^{\circ} \mathrm{C}$, and $150 \mathrm{rpm}$ agitation speed), and (d) adsorption temperature $\left(\mathrm{C}_{0}=55 \mathrm{ppm}, 0.2 \mathrm{~g} / 50 \mathrm{~mL}\right.$ adsorbent dose, $\mathrm{pH}$ 7, and $150 \mathrm{rpm}$ agitation speed) on the adsorption capacity of Lavandula pubescens Decne for removal of lead(II) ions from aqueous media. 


\subsubsection{Effect of Initial $\mathrm{Pb}$ (II) Ion Concentrations}

The effects of initial $\mathrm{Pb}(\mathrm{II})$ concentrations on the bioadsorption are represented in Figure $4 \mathrm{~b}$. When raising the initial $\mathrm{Pb}$ (II) ion concentration from 10 to $550 \mathrm{mg} / \mathrm{L}$, and keeping the other parameters constant $\left(0.2 \mathrm{~g} / 50 \mathrm{~mL}\right.$ adsorbent dose, $\mathrm{pH} 6$, temperature $=25^{\circ} \mathrm{C}$, and $150 \mathrm{rpm}$ agitation speed), the adsorption capacity increased. This higher metal uptake may be attributed to a higher collision probability of the metal ions with the plant sorbent material. At the highest metal ion concentration $(550 \mathrm{mg} / \mathrm{L})$, the adsorption capacity became almost constant, indicating a saturated state due to the limited number of active adsorption sites on the sorbent. The observed result is in line with previous studies using mango kernel [35], Eichhornia crassipes [23], and Oleander plant [36].

\subsubsection{Effect of Adsorbent Dosage}

The effect of sorbent dosage on the removal of $\mathrm{Pb}(\mathrm{II})$ was also evaluated under the following conditions: $0.1,0.2,0.5,1$, and $2 \mathrm{~g}$ adsorbent, $50 \mathrm{~mL}$ metal ion solution, $55 \mathrm{ppm}$ initial ion concentration, $2 \mathrm{~h}$ agitation time, $150 \mathrm{rpm}$ agitation speed, $\mathrm{pH} \sim 6$, and $25^{\circ} \mathrm{C}$ adsorption temperature. From the results in Figure $4 \mathrm{c}$, the highest adsorption capacity $\left(q_{e}, 14.2 \mathrm{mg} / \mathrm{g}\right)$ of $\mathrm{Pb}(\mathrm{II})$ was obtained at $0.1 \mathrm{~g}$ (the lowest experimental adsorbent dose); also, with increasing the dose from 0.1 to $0.5 \mathrm{~g}$ a noticeable rapid decrease in the adsorbent capacity, to $3.3 \mathrm{mg} / \mathrm{g}$, was observed.. The decreasing behavior of adsorption capacity at higher adsorbent dosage (i.e., above $0.5 \mathrm{~g}$ ) might be due to aggregation of the adsorption particles, preventing ions reaching the active sites on the adsorbent. However, it can be seen that, when further increasing the adsorption dosage above $0.5 \mathrm{~g}$, the removal percentage of $\mathrm{Pb}$ (II) did not change significantly, due to the maximal possible aggregation that may be reached [35]. These findings are consistent with previous studies, in which the dosage is an important factor for effective adsorption $[30,35,36]$. In reference to the isolated compounds, the chemical composition of the powdered LPD plant may facilitate such aggregation, that is, by physical and hydrogen bonding interaction between, for example, amides, esters, and alcoholic functionalities, meaning that the active site occupation becomes less in the highly compacted bulky materials at higher dose.

\subsubsection{Effect of Temperature}

The effect of temperature on the adsorption capacity was investigated at $30,35,40,45$, and $50{ }^{\circ} \mathrm{C}$, keeping the following parameters constant: adsorbate initial concentrations $55 \mathrm{mg} / \mathrm{L}$, absorbent dosage $0.2 \mathrm{~g}$, adsorption period $2 \mathrm{~h}$, and $\mathrm{pH}$ 7. The results depicted in Figure $4 \mathrm{~d}$ indicate endothermic adsorption mechanism, in which the $q_{e}$ value increased from 3.2 to $7.15 \mathrm{mg} / \mathrm{g}$ when temperature was raised from 30 to $50{ }^{\circ} \mathrm{C}$ [37]. Generally, the solution temperature plays a significant role in adsorption by influencing the equilibrium and rate of adsorption processes. Increasing the temperature enhances the diffusion rate of the adsorbate molecules and decreases the solution viscosity; both effects help ions move into adsorbent surfaces and pores of the biosorbent particles, as previously reported for natural plants [38,39] and natural bentonite clay [40]. On the other hand, temperature may facilitate breaking down of the physical and hydrogen bonds, reducing the aggregation events, leading to higher exposure of active sites on the adsorbent for $\mathrm{Pb}^{2+}$ ions and, thus, adsorption increase.

\subsubsection{Adsorption Isotherms}

In order to describe the adsorption equilibrium, the remaining heavy metal ion concentrations $\left(C_{e}\right.$, $\mathrm{mg} / \mathrm{g})$ in the solution and the adsorption capacity $\left(q_{e}, \mathrm{mg} / \mathrm{g}\right)$ were measured and correlated to each other. Langmuir and Freundlich adsorption models (Equations (3) and (4)) were used to fit the isotherm data obtained at different initial ion concentrations (Section 3.2.4) [23,36]. The analysis results are shown in Figure $5 \mathrm{a}, \mathrm{b}$, while the fitted parameters are listed in Table 5 . According to the results, the Freundlich isotherm fits the data better than the Langmuir model, with correlation coefficient $\left(R^{2}\right)$ values of 0.989 and 0.884 , respectively. The maximum adsorption capacity, $q_{m}$, calculated from Langmuir isotherm $\left(K_{L} 0.0074 \mathrm{~L} / \mathrm{mg}\right)$, corresponding to the monolayer coverage, was $91.32 \mathrm{mg} / \mathrm{g}$, however, 
the $K_{F}$ value indicates higher affinity for $\mathrm{Pb}^{2+}$ adsorption, compared to $K_{L}$. The equilibrium factor $R_{L}$ (dimensionless), Equation (11), is one essential feature of the Langmuir equation, describing the adsorption shape and, therefore, the degree to which the adsorption process is favored: $R_{L}>1$, unfavorable monolayer process; $R_{L}=1$, linear; $0<R_{L}<1$, favorable; and $R_{L}=0$, irreversible [41].

$$
R_{L}=\frac{1}{1+K_{L} C_{0}}
$$
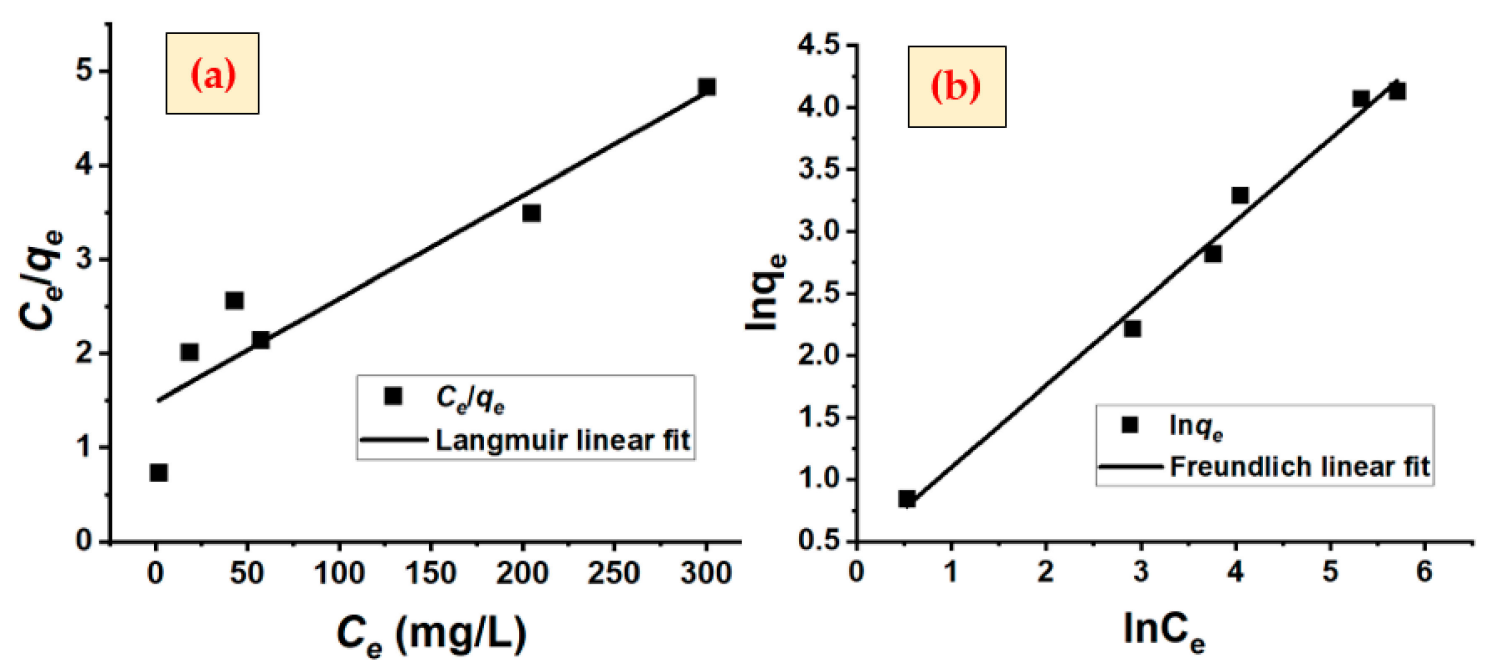

Figure 5. Linearized Langmuir (a) and Freundlich (b) isotherm equations. Conditions: 10-550 ppm $\mathrm{Pb}^{2+}$ concentration, $50 \mathrm{~mL} \mathrm{~Pb}^{2+}$ solution volume, $0.2 \mathrm{~g}$ LPD adsorbent dose, $\mathrm{pH} 6,25^{\circ} \mathrm{C}$ adsorption temperature, and $150 \mathrm{rpm}$ agitation speed.

Table 5. Parameters obtained from Langmuir and Freundlich isotherm models for adsorption of $\mathrm{Pb}^{2+}$ ion onto LPD.

\begin{tabular}{cccccccccc}
\hline Adsorbent & & \multicolumn{3}{c}{ Langmuir } & \multicolumn{4}{c}{ Freundlich } \\
\hline \multirow{2}{*}{$\mathrm{LPD}$} & $q_{m}(\mathrm{mg} / \mathrm{g})$ & $K_{L}(\mathrm{~L} / \mathrm{mg})$ & $R^{2}$ & $R_{L}\left(\right.$ at $\left.C_{0}(\mathrm{mg} / \mathrm{g})=165,550\right)$ & $K_{F}$ & $1 / n$ & $n$ & $R^{2}$ \\
\cline { 2 - 10 } & 91.32 & 0.0074 & 0.884 & $0.450,0.024$ & 2.722 & 0.662 & 1.511 & 0.989 \\
\hline
\end{tabular}

The obtained $R_{L}$ values (Table 5) are between zero and the unity, thus indicating a favorable adsorption process. The Freundlich model is also characterized by the heterogeneity factor, $1 / n$, with value of 0.662 indicating good adsorption of $\mathrm{Pb}^{2+}$ ions by the adsorbent LPD. Generally, the adsorption is a more suitable fit to Freundlich, and both the separation factor $\left(R_{L}\right)$ and the heterogeneity factor $(1 / n)$ indicate a favorable adsorption process on a heterogeneous surface with a tendency toward chemisorption mechanism.

\subsubsection{Adsorption Thermodynamics}

The thermodynamic parameters, including $\Delta G^{\circ}, \Delta H^{\circ}$, and $\Delta S^{\circ}$, can be obtained from the van't Hoff equation, Equation (8), as shown in Figure 6 and Table 6. The positive values of the three parameters indicate an endothermic and nonspontaneous process. However, the adsorption system is greatly dependent on adsorption temperature, becoming spontaneous at high temperature where $T \Delta S$ outweighs $\Delta H$. The positive value of $\Delta S^{\circ}$ also suggests an increase in the randomness at the solid-liquid interface during the adsorption. 


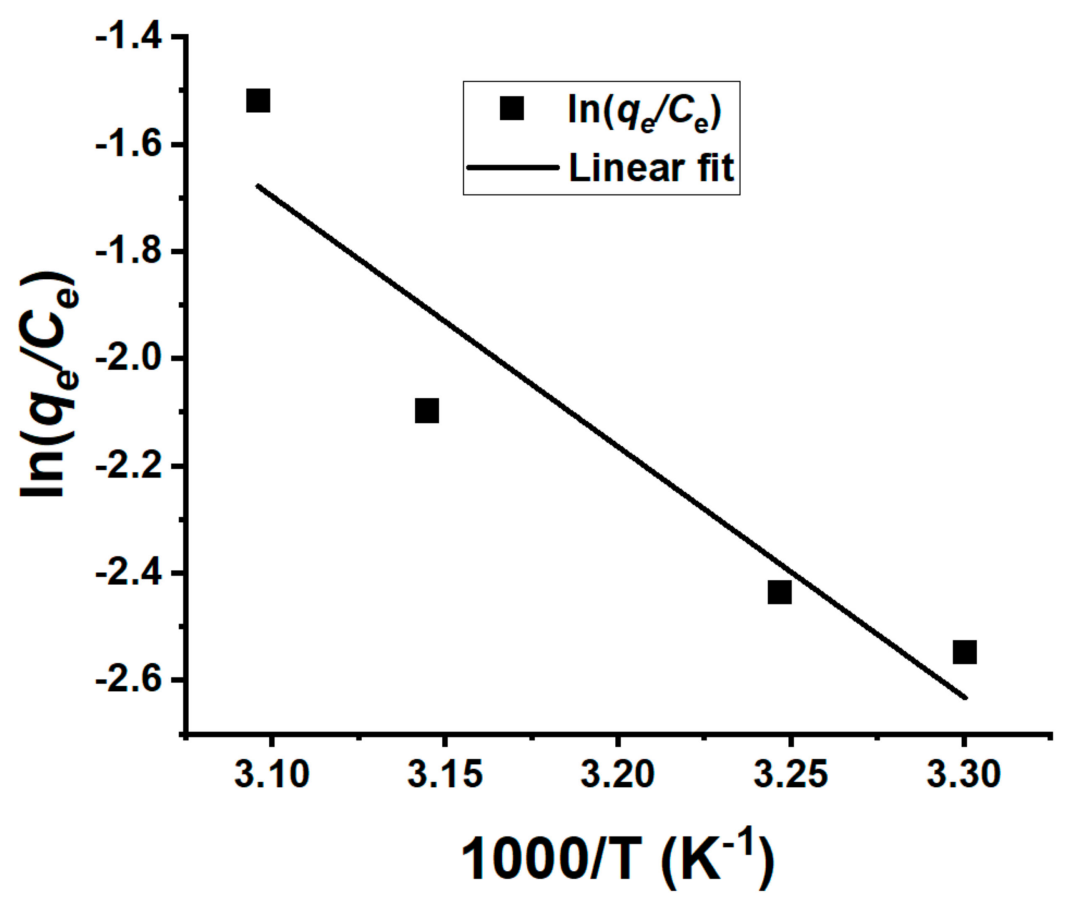

Figure 6. Van't Hoff plot for the adsorption of $\mathrm{Pb}^{2+}$ onto Lavandula pubescens Decne adsorbent.

Table 6. Thermodynamic parameters for lead(II) ion adsorption onto LPD adsorbent.

\begin{tabular}{|c|c|c|c|c|c|}
\hline$T(\mathrm{~K})$ & $\ln K_{s}$ & $\Delta G^{\circ}(\mathrm{kJ} / \mathrm{mol})$ & $\Delta H^{\circ}(\mathrm{kJ} / \mathrm{mol})$ & $\Delta S^{\circ}(\mathrm{J} / \mathrm{mol} \cdot \mathrm{K})$ & $R^{2}$ \\
\hline 303 & -2.547 & 6.417 & \multirow{4}{*}{38.814} & \multirow{4}{*}{106.211} & \multirow{4}{*}{0.8871} \\
\hline 308 & -2.437 & 6.239 & & & \\
\hline 318 & -2.097 & 5.545 & & & \\
\hline 323 & -1.519 & 4.079 & & & \\
\hline
\end{tabular}

Based on the discussed overall results, the adsorption mechanism is an endothermic, PSO, chemical process governed by the Freundlich heterogeneous surface, and is more favorable at high temperature.

Lavandula pubescens is abundantly available in Saudi Arabia, particularly in the western region, and can be collected for free as a raw, low-cost material for, e.g., medical, pharmaceutical, and environmental applications [20,21]. However, as Lavandula pubescens biomass used in this work is an abundant wild plant, it can be assumed as a low-cost material, and recovery of the spent adsorbent may be costlier, compared to the raw material itself; therefore, reusability experiments were not further pursued.

\subsection{Relative Performance of LPD Biosorbent}

A comparison of the adsorption performance of LPD biomass in removal of lead ion from contaminated water with those of various biosorbents reported in literature is shown in Table 7. For simplicity of comparison, the maximum adsorption capacity $\left(q_{m}\right)$ of the biosorbents, as well as the corresponding adsorption conditions, were tabulated. As can be seen, the predicted $q_{m}$ value of LPD is relatively higher than most of the listed values. It is worth mentioning that, despite no modifications having been carried out on the LPD surface characteristic, its potential for removal of lead(II) is noticeable, and modification may further enhance its adsorption capacity [29]. Adsorption enhancement of modified biosorbent is proven by the work of Calero et al. [42], in which the obtained $q_{m}$ values of untreated-, $\mathrm{H}_{2} \mathrm{SO}_{4}{ }^{-}, \mathrm{HNO}_{3}{ }^{-}$, and $\mathrm{NaOH}$-oil tree pruning biosorbents were 
$27.05,65.62,85.09$, and $121.60 \mathrm{mg} / \mathrm{g}$, respectively. The difference in the adsorption capacities of various biomasses is attributed to the variety in the chemical and textural properties, including their functional groups' type and abundance. Adsorption conditions are also one important influencer in the adsorption performance of the adsorbent, therefore, optimization of the adsorption parameters may enhance the adsorption efficiency.

Table 7. Comparison of biosorption capacity of various biosorbents for lead(II) ions from aqueous solution.

\begin{tabular}{|c|c|c|c|c|c|c|}
\hline \multirow[b]{2}{*}{ Biosorbent } & \multirow[b]{2}{*}{$q_{m}(\mathrm{mg} / \mathrm{g})$} & \multicolumn{4}{|c|}{ Adsorption Conditions } & \multirow[b]{2}{*}{ Reference } \\
\hline & & $C_{0}(\mathrm{mg} / \mathrm{L})$ & $\mathrm{pH}$ & $T\left({ }^{\circ} \mathrm{C}\right)$ & $\begin{array}{c}\text { Adsorbent } \\
\text { Dosage (g/L) }\end{array}$ & \\
\hline Schoenoplectus californicus & 16.85 & $2.1-414.4$ & 5 & $25 \pm 1$ & 5 & [30] \\
\hline Banana peels & 2.18 & $30-80$ & 5 & 25 & 40 & [28] \\
\hline Ulva lactuca & 34.7 & $10-275$ & 5 & 20 & 20 & [29] \\
\hline Moringa oleifera leaves & 45.83 & 80 & 6 & Room T. & 1.5 & [43] \\
\hline Solanum melongena leaf & 55.55 & $30-90$ & 5 & 30 & 0.4 & [44] \\
\hline Untreated-Olive tree pruning & 27.05 & \multirow{4}{*}{$40-2400$} & \multirow{4}{*}{5} & \multirow{4}{*}{25} & \multirow{4}{*}{10} & \multirow{4}{*}{ [42] } \\
\hline $\mathrm{H}_{2} \mathrm{SO}_{4}$-Olive tree pruning & 65.62 & & & & & \\
\hline $\mathrm{HNO}_{3}$-Olive tree pruning & 85.09 & & & & & \\
\hline $\mathrm{NaOH}-\mathrm{Olive}$ tree pruning & 121.60 & & & & & \\
\hline Lavandula pubescens Decne & 91.32 & $10-550$ & 6 & 25 & 4 & This work \\
\hline
\end{tabular}

\section{Conclusions}

In this investigation, the dried aerial parts of a shrub, L. pubescens, were tested as a low-cost, abundant, and environmentally-friendly adsorbent for removal of $\mathrm{Pb}$ (II) ions from water. The considered variables were: initial metal ion concentrations, solution $\mathrm{pH}$, contact time, temperature, and adsorbent dosage. The adsorption efficiency was correlated to the chemical constituents of L. pubescens analyzed by GC/MS and GLC techniques. The result revealed optimal capacity at $\mathrm{pH}=5$, contact time of $90 \mathrm{~min}$, at low biosorbent dosage, and at higher-temperature and ion initial-concentration. The adsorption isotherms could be better described by the Freundlich model, indicating a multilayer adsorption process. Moreover, the adsorption kinetic obeyed the pseudo-second-order, suggesting a chemisorption process; and evidenced by the thermodynamic data. The adsorption system was found to be endothermic, nonspontaneous, and favored at higher temperature.

Author Contributions: Data curation: F.A.A. and M.A.; formal analysis: M.A.; funding acquisition: F.A.A., A.Q.A., and A.E.-M.; investigation: A.Q.A. and K.A.A.; methodology: F.A.A., N.A.-Z., and A.E.-M.; project administration: A.Q.A.; software: F.A.A.; validation: N.A.-Z.; Writing-Original draft: A.Q.A.; Writing-Review and editing: A.Q.A. All authors have read and agreed to the published version of the manuscript.

Funding: The authors extend their appreciation to the Deanship of Scientific Research at King Saud University for funding this work through the research group No. RGP-1441-305. The authors gratefully acknowledge the financial support by the Deanship of Scientific Research at Albaha University through Project No: 1441/3.

Conflicts of Interest: The authors declare no conflict of interest.

\section{References}

1. Ayyappan, R.; Sophia, A.C.; Swaminathan, K.; Sandhya, S. Removal of Pb (II) from aqueous solution using carbon derived from agricultural wastes. Process. Biochem. 2005, 40, 1293-1299. [CrossRef]

2. Lee, J.-C.; Son, Y.-O.; Pratheeshkumar, P.; Shi, X. Oxidative stress and metal carcinogenesis. Free Radic. Biol. Med. 2012, 53, 742-757. [CrossRef] [PubMed]

3. Nagajyoti, P.C.; Lee, K.D.; Sreekanth, T. Heavy metals, occurrence and toxicity for plants: A review. Environ. Chem. Lett. 2010, 8, 199-216. [CrossRef] 
4. Afroze, S.; Sen, T.K. A review on heavy metal ions and dye adsorption from water by agricultural solid waste adsorbents. Water Air Soil Pollut. 2018, 229, 225. [CrossRef]

5. Dridi, C.; Youcef, L. Removal of lead by adsorption on kaolin. Larhyss J. P-ISSN 1112-3680/E-ISSN 2521-9782 2016, 13, 7-22.

6. Shaalan, H.; Sorour, M.; Tewfik, S. Simulation and optimization of a membrane system for chromium recovery from tanning wastes. Desalination 2001, 141, 315-324. [CrossRef]

7. Song, S.; Lopez-Valdivieso, A.; Hernandez-Campos, D.; Peng, C.; Monroy-Fernandez, M.; Razo-Soto, I. Arsenic removal from high-arsenic water by enhanced coagulation with ferric ions and coarse calcite. Water Res. 2006, 40, 364-372. [CrossRef]

8. Alyüz, B.; Veli, S. Kinetics and equilibrium studies for the removal of nickel and zinc from aqueous solutions by ion exchange resins. J. Hazard. Mater. 2009, 167, 482-488. [CrossRef]

9. Srinivasan, R. Role of Plant. Biomass in Heavy Metal. Treatment of Contaminated Water; Anuradha Mishra, J.H.C., Ed.; Royal Society of Chemistry: Cambridge, UK, 2013. [CrossRef]

10. Khan, M.A.; Alqadami, A.A.; Otero, M.; Siddiqui, M.R.; Alothman, Z.A.; Alsohaimi, I.; Rafatullah, M.; Hamedelniel, A.E. Heteroatom-doped magnetic hydrochar to remove post-transition and transition metals from water: Synthesis, characterization, and adsorption studies. Chemosphere 2019, 218, 1089-1099. [CrossRef]

11. Li, X.; Li, D.; Yan, Z.; Ao, Y. Adsorption of cadmium by live and dead biomass of plant growth-promoting rhizobacteria. RSC Adv. 2018, 8, 33523-33533. [CrossRef]

12. de Gisi, S.; Lofrano, G.; Grassi, M.; Notarnicola, M. Characteristics and adsorption capacities of low-cost sorbents for wastewater treatment: A review. Sustain. Mater. Technol. 2016, 9, 10-40. [CrossRef]

13. Jafari-Kang, A.; Baghdadi, M.; Pardakhti, A. Removal of cadmium and lead from aqueous solutions by magnetic acid-treated activated carbon nanocomposite. Desalin. Water Treat. 2016, 57, 18782-18798. [CrossRef]

14. Huang, C.; Blankenship, D. The removal of mercury (II) from dilute aqueous solution by activated carbon. Water Res. 1984, 18, 37-46. [CrossRef]

15. Jain, C.K.; Malik, D.S.; Yadav, A.K. Applicability of plant based biosorbents in the removal of heavy metals: A review. Environ. Process. 2016, 3, 495-523. [CrossRef]

16. Derbe, T.; Batu, H.D.W. Cactus potential in heavy metal ( $\mathrm{Pb}$ and $\mathrm{Cd}$ ) removal in water sample collected from rural area around Adigrat town. Digestion 2015, 5, 11.

17. Dhir, B.; Kumar, R. Adsorption of heavy metals by Salvinia biomass and agricultural residues. Int. J. Environ. Res. 2010, 4, 427-432. [CrossRef]

18. Hossain, M.; Ngo, H.H.; Guo, W.; Nguyen, T. Removal of copper from water by adsorption onto banana peel as bioadsorbent. Int. J. Geomate 2012, 2, 227-234. [CrossRef]

19. Seniūnaitè, J.; Vaiškunait, R.; Bolutien, V. Coffee grounds as an adsorbent for copper and lead removal form aqueous solutions. In Proceedings of The 9th International Conference "Environmental Engineering"; VGTU Press: Vilnius, Lithuania, 2014. [CrossRef]

20. Minooeianhaghighi, M.; Sepehrian, L.; Shokri, H. Antifungal effects of Lavandula binaludensis and Cuminum cyminum essential oils against Candida albicans strains isolated from patients with recurrent vulvovaginal candidiasis. J. Mycol. Med. 2017, 27, 65-71. [CrossRef]

21. Al-Badani, R.N.; da Silva, J.K.R.; Mansi, I.; Muharam, B.A.; Setzer, W.N.; Awadh Ali, N.A. Chemical composition and biological activity of Lavandula pubescens essential oil from Yemen. J. Essent. Oil Bear. Plants 2017, 20, 509-515. [CrossRef]

22. Al-Senani, G.M.; Al-Fawzan, F.F. Study on adsorption of $\mathrm{Cu}$ and $\mathrm{Ba}$ from aqueous solutions using nanoparticles of Origanum (OR) and Lavandula (LV). Bioinorg. Chem. Appl. 2018, 2018, 3936178. [CrossRef]

23. Li, Q.; Chen, B.; Lin, P.; Zhou, J.; Zhan, J.; Shen, Q.; Pan, X. Adsorption of heavy metal from aqueous solution by dehydrated root powder of long-root Eichhornia crassipes. Int. J. Phytoremed. 2016, 18, 103-109. [CrossRef] [PubMed]

24. Ho, Y.-S.; McKay, G. Pseudo-second order model for sorption processes. Process. Biochem. 1999, 34, 451-465. [CrossRef]

25. Gouda, B.; Mousa, O.; Salama, M.; Kassem, H. Volatiles and lipoidal composition: Antimicrobial activity of flowering aerial parts of Lavandula pubescens Decne. Int. J. Pharmacogn. Phytochem. Res. 2017, 9. [CrossRef]

26. Akhlaghi, H.; Shafaghat, A.; Salimi, F.; Mohammadhoseini, M. GC-MS analysis of the essential oil from wild Stachys pubescens ten leaves from Northwest Iran. Anal. Chem. Lett. 2011, 1, 325-327. [CrossRef] 
27. Alghamdi, A.A.; Al-Odayni, A.-B.; Saeed, W.S.; Al-Kahtani, A.; Alharthi, F.A.; Aouak, T. Efficient adsorption of lead (II) from aqueous phase solutions using polypyrrole-based activated carbon. Materials 2019, 12, 2020. [CrossRef]

28. Anwar, J.; Shafique, U.; Salman, M.; Dar, A.; Anwar, S. Removal of Pb (II) and Cd (II) from water by adsorption on peels of banana. Bioresour. Technol. 2010, 101, 1752-1755. [CrossRef]

29. Sarı, A.; Tuzen, M. Biosorption of $\mathrm{Pb}$ (II) and $\mathrm{Cd}$ (II) from aqueous solution using green alga (Ulva lactuca) biomass. J. Hazard. Mater. 2008, 152, 302-308. [CrossRef]

30. Rearte, T.A.; Bozzano, P.B.; Andrade, M.L.; Fabrizio de Iorio, A. Biosorption of Cr (III) and Pb (II) by Schoenoplectus californicus and Insights into the Binding Mechanism. ISRN Chem. Eng. 2013, 2013, 851602. [CrossRef]

31. Ibrahim, W.M. Biosorption of heavy metal ions from aqueous solution by red macroalgae. J. Hazard. Mater. 2011, 192, 1827-1835. [CrossRef]

32. Li, Y.; Du, Q.; Wang, X.; Zhang, P.; Wang, D.; Wang, Z.; Xia, Y. Removal of lead from aqueous solution by activated carbon prepared from Enteromorpha prolifera by zinc chloride activation. J. Hazard. Mater. 2010, 183, 583-589. [CrossRef]

33. Mohammod, M.; Sen, T.K.; Maitra, S.; Dutta, B.K. Removal of Zn 2+ from aqueous solution using castor seed hull. Water Air Soil Pollut. 2011, 215, 609-620. [CrossRef]

34. FENG, N.-C.; GUO, X.-Y. Characterization of adsorptive capacity and mechanisms on adsorption of copper, lead and zinc by modified orange peel. Trans. Nonferrous Met. Soc. China 2012, 22, 1224-1231. [CrossRef]

35. Akram, M.; Bhatti, H.N.; Iqbal, M.; Noreen, S.; Sadaf, S. Biocomposite efficiency for Cr (VI) adsorption: Kinetic, equilibrium and thermodynamics studies. J. Environ. Chem. Eng. 2017, 5, 400-411. [CrossRef]

36. Abu-El-Halawa, R.; Zabin, S.; Abu-Sittah, H. Investigation of methylene blue dye adsorption from polluted water using oleander plant (Al defla) tissues as sorbent. Am. J. Environ. Sci. 2016, 12, 213-224. [CrossRef]

37. Saha, R.; Mukherjee, K.; Saha, I.; Ghosh, A.; Ghosh, S.K.; Saha, B. Removal of hexavalent chromium from water by adsorption on mosambi (Citrus limetta) peel. Res. Chem. Intermed. 2013, 39, 2245-2257. [CrossRef]

38. Barka, N.; Abdennouri, M.; el Makhfouk, M.; Qourzal, S. Biosorption characteristics of cadmium and lead onto eco-friendly dried cactus (Opuntia ficus indica) cladodes. J. Environ. Chem. Eng. 2013, 1, 144-149. [CrossRef]

39. Afroze, S.; Sen, T.K.; Ang, H.M. Adsorption removal of zinc (II) from aqueous phase by raw and base modified Eucalyptus sheathiana bark: Kinetics, mechanism and equilibrium study. Process. Saf. Environ. Prot. 2016, 102, 336-352. [CrossRef]

40. Sen, T.K.; Gomez, D. Adsorption of zinc $\left(\mathrm{Zn}^{2+}\right)$ from aqueous solution on natural bentonite. Desalination 2011, 267, 286-294. [CrossRef]

41. Alghamdi, A.A.; Al-Odayni, A.-B.; Saeed, W.S.; Almutairi, M.S.; Alharthi, F.A.; Aouak, T.; Al-Kahtani, A. Adsorption of Azo Dye Methyl orange from aqueous solutions using alkali-activated polypyrrole-based graphene oxide. Molecules 2019, 24, 3685. [CrossRef] [PubMed]

42. Calero, M.; Pérez, A.; Blázquez, G.; Ronda, A.; Martín-Lara, M.A. Characterization of chemically modified biosorbents from olive tree pruning for the biosorption of lead. Ecol. Eng. 2013, 58, 344-354. [CrossRef]

43. Imran, M.; Anwar, K.; Akram, M.; Shah, G.M.; Ahmad, I.; Samad Shah, N.; Khan, Z.U.H.; Rashid, M.I.; Akhtar, M.N.; Ahmad, S. Biosorption of Pb (II) from contaminated water onto Moringa oleifera biomass: Kinetics and equilibrium studies. Int. J. Phytoremed. 2019, 21, 777-789. [CrossRef] [PubMed]

44. Yuvaraja, G.; Krishnaiah, N.; Subbaiah, M.V.; Krishnaiah, A. Biosorption of Pb (II) from aqueous solution by Solanum melongena leaf powder as a low-cost biosorbent prepared from agricultural waste. Colloids Surf. B 2014, 114, 75-81. [CrossRef] [PubMed]

Publisher's Note: MDPI stays neutral with regard to jurisdictional claims in published maps and institutional affiliations. 